\title{
A STUDY ON THE TERATOGENIC EFFECT OF CIPROFLOXACIN
}

\author{
SELIM MOHAMMED JAHANGIR ${ }^{1}$, AFM SAIFUL ISLAM ${ }^{2}$
}

Assistant Professor ${ }^{1}$, Department of Pharmacology \& Therapeutics, Chittagong Medical College, Chittagong, Professor ${ }^{2}$, Department of Pharmacology \& Therapeutics, Comilla Medical College, Comilla

\begin{abstract}
:
Drugs or medicinal agent should only be used in pregnancy if there is proven benefit to the mother and no potential teratogenic risks. Present study was performed to evaluate the teratogenic effect of modern drug, Ciprofloxacin a Fluoroquinolone derivative, which has been introduced in Bangladesh. This was felt necessary because this has been found to be used indiscriminately at all levels of the prescribers and there is no strong evidence to its safety in pregnancy. The work described here is to evaluate the teratogenic effect of Ciprofloxacin using swiss albino mice. The pregnant mice were divided into two different groups which received Normal Saline and Ciprofloxacin $25 \mathrm{mg} / \mathrm{kg}$ body weight.] given from $6^{\text {h }}$ to $15^{\text {th }}$ day of gestation. Neither the control group nor the experimental group revealed any sign of external deformity and cleft palate.
\end{abstract}

(Bangladesh J Physiol Pharmacol 2006; 22(1/2) : 9-11)

\section{INTRODUCTION:}

Descriptions of congenital abnormalities may be found in pre-Aristotelian times, but it was Aristotle who made a first attempt at causal analysis, and thus introduced the scientific approach to problems of teratology ${ }^{1}$.Pharmacological screening of any new drug or medicinal agent for its teratogenic potentiality has become mandatory before use in human beings following Thalidomide disaster in early 1960. Teratology is the branch of embryology that deals with all features of abnormal development, including the structure of its endproducts. Teratogenesis is derived from teratogen (i.e. monster-producing), Greek term for monster, is an agent which produces major anatomical abnormalities, such as cleft palate, phocomelia or anencephaly ${ }^{2}$, nonreversible morphological changes present at birth. These changes are of an irreversible nature since the organism cannot repair them during its subsequent development by growth or regenerative processes. The incidence of teratogenesis is reported to be one infant in fourteen that survives the neonatal period and bears a malformation of some kind and degree, whereas those dying earlier have a much higher incidence. In no other field of medicine is the therapeutic risk higher than in the treatment of pregnant women. It is, therefore, desirable for the prescribers to have information on a new compound's potential risk to the foetus so that the risks can be weighed against the potential benefit to the

Address of Correspondence: Selim Mohammed Jahangir, Assistant Professor, Department of Pharmacology \& Therapeutics, Chittagong Medical College, Chittagong mother. In view of this, the present study seemed worthy to investigate the teratogenic effect of the Ciprofloxacin a Fluoroquinolone derivative.

Ciprofloxacin is one of the most recent advancement of Fluoroquinolone derivatives in the field of synthetic antimicrobial agents. It has a greater intrinsic antibacterial activity and a broader antimicrobial spectrum than Nalidixic Acid, which was first widely used as urinary antiseptic in 1963, because of its high concentration in urine ${ }^{3}$. Because of little systemic activity ${ }^{4}$ and rapid development of bacterial resistance ${ }^{5}$, Nalidixic Acid provides limited therapeutic utility. Against this backdrop, Ciprofloxacin represents a particularly important therapeutic advance, as this agent has broad antimicrobial activity for the treatment of a variety of infectious diseases, few side effects and microbial resistance to its action does not develop rapidly ${ }^{5}$. With wide spectrum of antimicrobial activity, Ciprofloxacin has excellent activity against the Enterobacteriaceae ${ }^{6}$, e.g. Klebsiella, Proteus, Salmonella, Shigella, Escherichia coli, including Pseudomonas aeruginosa ${ }^{7}$ and many organisms resistant to penicillins, cephalosporins and is also effective against Haemophilus influenzae, Neisseria gonorrhoeae and Campylobacter ${ }^{6}$. Bone and soft tissue infections caused by Staphylococci and gramnegative microorganisms have been treated effectively with Ciprofloxacin ${ }^{8}$. Ciprofloxacin also show promise in reducing the incidence of infections in immunocompromised patients, gonococcal infection and cystic fibrosis ${ }^{3}$. 
Data showing that Ciprofloxacin is a relatively safe antimicrobial drug has been gathered from extensive clinical trials with this drug $^{9}$. Concern over possible joint damage is the reason that Ciprofloxacin is not recommended for therapy of infections in these under 18 years of age and in pregnancy ${ }^{10}$. Besides the question of cartilage damage in growing children, we have also reports ${ }^{11,12}$ that addressed the teratogenic and embryotoxic effect of the drug. Teratogenicity, while of concern, has not yet been shown to be of clinical importance ${ }^{13,14}$. A through review of literature could not locate similar study in our country although the use of Ciprofloxacin seems to be gradually increasing.

This perspective certainly points to the need for toxicologic study of Ciprofloxacin in context of Bangladesh situation. With this objective in view, the present study was done to demonstrate the teratogenic effects of Ciprofloxacin in mice.

\section{MATERIALSAND METHODS:}

Animals: The experiment was carried out in Swiss albino female virgin mice of 2-3 months old, weighing 25-30 gram, bred in the laboratory. One male of the same strain was caged with four females and were fed standard animal pellets with water ad libitum. The animals were maintained in natural dark/light schedule. The females were examined daily between 10 a.m. to noon to see the vaginal plugs. Those animals demonstrating vaginal plugs were isolated and the day on which the vaginal plugs were observed was considered day 1 of pregnancy. As it was assumed that conception occurred in the early morning ${ }^{15}$, conception was arbitrarily computed as having occurred 6 hours previously. For any individual animal, the maximum possible error in timing was, therefore, plus or minus 6 hours. This was similar to the previous experiment ${ }^{16}$ to show cleft palate development in offsprings after cortisone carried out in mice. The pregnant mice thus isolated were then subjected to drug treatment.

\section{Drugs:}

Ciprofloxacin: This was available in the form of tablet ( Bayer, Leverkusen, Germany), Suspension was made with Normal Saline containing $0.75 \mathrm{mg} / \mathrm{ml}$.

\section{Protocol:}

The pregnant mice were randomly divided into following groups:

Group-I [Control] : Received $1 \mathrm{ml}$ of Normal Saline orally.

Group-II

:Received $1 \mathrm{ml}$ of Ciprofloxacin suspension orally in a dose of 25 $\mathrm{mg} / \mathrm{kg}$ body weight.

Drugs or vehicle were given once daily between 10 and 11 a.m. from $6^{\text {th }}$ to $15^{\text {th }}$ day of gestation. The duration of drug treatment was selected on the basis of previous report ${ }^{17}$ that showed $6^{\text {th }}$ to $15^{\text {th }}$ days of gestation as the most crucial period of organogenesis in mice and thus provide suitable time to study teratogenic effects of drugs. The dose of Ciproflaxacin was determined depending on the previous study ${ }^{11,12,13}$ of Ciprofloxacin toxicity. On the $17^{\text {th }}$ day of gestation fetuses were removed by Caesarean section of the pregnant mice under light Ether anaesthesia. This was determined by taking 19 days as average gestational period from previous study ${ }^{16}$. The removed fetuses were then observed for the presence of any gross signs of external deformities and the presence of cleft palate. The observation of the palate was done after excision of the upper portion of the head. The buccal musculature was then cut and the lower jaw and tongue were displaced. A palate was considered full (i.e. normal) only when there was well-developed rugae and no cleft, full or partial, was present ${ }^{18}$.

\section{RESULTS:}

No signs of external deformity and neither partial nor full cleft was detected in any of the fetuses of the mice that received Salina or Ciprofloxacin.

Table:

\begin{tabular}{ccccc}
\hline $\begin{array}{c}\text { Group } \\
\text { mice }\end{array}$ & $\begin{array}{c}\text { No. of } \\
\text { offsprings }\end{array}$ & $\begin{array}{c}\text { No. of } \\
\text { offsprings } \\
\text { showing external } \\
\text { deformity }\end{array}$ & $\begin{array}{c}\text { No. of } \\
\text { offsprings } \\
\text { showing } \\
\text { presence of } \\
\text { cleft palate }\end{array}$ \\
\hline 1 & 10 & 125 & 0 & 0 \\
$\|$ & 99 & 0 & 0 \\
\hline
\end{tabular}

I= Pregnant mice received $1 \mathrm{ml}$ of Normal Saline [Control]

$\mathrm{II}=$ Pregnant mice received $1 \mathrm{ml}$ of prepared Ciprofloxacin suspension 


\section{DISCUSSION:}

Judicious use of drugs is gradually becoming the focus of intense interest in medical practice. In recent years, the interest has manifested by repeated, both preclinical and clinical, testing of new drugs or medicinal agents throughout the world. Although the toxic ability of drugs to produce malformation in offsprings when given to pregnant mothers did not gain much importance before the well-known disaster caused by Thalidomide, it is now well recognized that both extensive preclinical and post-marketing surveillance are fundamental requirements to avoid parallel misfortune in future. The value of animal screening is borne out by the fact that all drugs that have been established as teratogens in man can be shown to be teratogenic in animals. Likewise, drugs shown to be teratogenic in animals may be teratogenic in man under appropriate conditions of dosage and timing. With the principal objective in view, the present study was carried out to investigate the teratogenic effects of Ciprofloxacin that seems to be very promising with high exposure frequency as an antimicrobials in the current medical practice. Rats or mice are frequently used in teratological studies since they are widely available, have large litters, reproduce freely and perhaps most important of all, many background data are available for them. Results of the experiments did not show any evidence of any external deformity nor there was failure of palate formation in offsprings of Control and Ciprofloxacin treated mice. These indicated, absence of teratogenic as well as embryotoxic effect of Ciprofloxacin. The prediction and extrapolation of animal experiment data, especially in relation to teratogenesis in humans is somewhat limited. Considering all these, the results of the present study which have direct clinical significance warrant further works using different experimental animal and methodology.

\section{ACKNOWLEDGEMENT:}

One of the authors [Selim Mohammed Jahangir] was supported partially by a grant from BMRC, Dhaka, Bangladesh.

\section{REFERENCES:}

1. Waelsch SG. Trends in mammalian teratology. Pediatrics 1957; 19:777-81.

2. Tuchmann-Duplessis H. Embryonic Clinical Pharmacology. In: Speight TM, editor. Avery's Drug Treatment Principles and Practice of Clinical Pharmacology and Therapeutics, $3^{\text {rd }}$ ed. Auckland: AIDS Press Limited, 1987: 65-78.
3. Reynolds JEE, Parfit K, Parsons AV, Sweetman SC. editors. Martindale The Extra Pharmacopoeia, $29^{\text {th }}$ ed. London: The Pharmaceutical Press, 1989.

4. Laurence DR, Bennett PN. Clinical Pharmacology, $7^{\text {th }}$ ed. London: ELBS, Churchill Livingstone, 1992: 173.

5. Mandell GL, Sande MA. Antimicrobial agents. In: Gilman AG, Rall TW, Nies AS, Taylor P, editors. Goodman and Gilman's the Pharmacological Basis of Therapeutics, $8^{\text {th }}$ ed. Singapore: Pergamon Press, Inc., 1991: 1047-1064.

6. Rang HP, Dale MM. Pharmacology, $2^{\text {nd }}$ ed. UK: ELBS Churchill Livingstone, 1991

7. Fass RJ. Ciprofloxacin: Best use of this new broad spectrum antibiotic. Postgrad Med 1990; 87: 117-131.

8. Greenberg et al., 1987; cited by Mandell GL, Sande MA. Antimicrobial agents. In: Gilman AG, Rall TW, Nies AS, Taylor P, editors. Goodman and Gilman's the Pharmacological Basis of Therapeutics, $8^{\text {th }}$ ed. Singapore: Permagon Press, Inc., 1991: 1047-1064.

9. Arcieri G, Griffith E, Gruenwaldt $G$ et al. Ciprofloxacin: An update on clinical experience. Am J Med 1987; 82(Suppl. 4A) : S381-S386.

10. Schluter G. Ciprofloxacin: Review of potential toxicologic effects. Am J Med 1987; 82(Suppl. 4A): S91-S93.

11. Jensen $\mathrm{T}$, Pedersen $\mathrm{S}$, Nielsen $\mathrm{CH}$, Hoiby $\mathrm{N}$, Kock $\mathrm{C}$. The efficacy and safety of Ciprofloxacin and Ofloxacin in chronic Pseudomonas aeruginosa in cystic fibrosis. J Antimicrob Chemother 1987; 20:585-594.

12. Reiter C, Pfeiffer M, Hullmann RN. Brief report: Safety of Ciprofloxacin based on phase IV (Anwendungsbeobachtung) in Federal Republic of Germany. Am J Med 1989: 87(Suppl. 5A) : S103-S106.

13. Schluter G. Ciprofloxacin: toxicologic evaluation of additional safety data. Am J Med 1989; 87(Suppl. 5A) : S37-S39.

14. Wolfson JS, Hooper DC. Overview of Fluoroquinolone safety. Am J Med 1991; 91(Suppl. 6A) : S153-S161.

15. Runner MN, Ladman AJ. The time of ovulation and its diurnal regulation in the postparturitional mouse. Anal Rec 1950; 108: 343-361.

16. Kalter $\mathrm{H}$. Factors influencing the frequency of Cortisoneinduced cleft palate in mice. J Exp 1957; 2001: 449-520.

17. Dagg CP. Teratogenesis. In: Green EL, editor. Biology of Laboratory Mouse, $2^{\text {nd }}$ ed. New York: McGraw-Hill, 1966: 309-328.

18. Peer LA, Bryan WH, Strean LP, Walker JC, Bernhard WG, Peck GC. Induction of cleft palate in mice by Cortisone and its reduction by vitamins. J Int Coll Surg 1958; 30: 249-254. 